\title{
MASALAH GIZI DAN PERAN GIZI SEIMBANG
}

\author{
Dyah Titin Laswati ${ }^{1}$
}

\begin{abstract}
Good nutrition will be consistent with good health. In the clinical symptoms of malnutrition is the body's growth and not normal development. Nutritional status was the final result of the various factors that may relate to one anothers. Therefore, understanding how the nutrient problems should be the basis for a strategy for the prevention and mitigation. The nutritional status is directly influenced by two things, the adequacy of nutrient intake to meet the needs of the body and the infection status of a person, mutually influential, so fixing one of them is not going to fix the state of the other. The guidelines of balanced nutrition was the best solution in Indonesia visualized in Tumpeng of balanced nutrition. Data of nutritional health status and nutrition-related non-communicable diseases of data obtained from the Health Research by the Ministry of Health, 2010 and micronutrient status data, especially iron deficiency anemia status. The agreement of the World Food Conference in Rome in 1992 set of recommendations to all countries, particularly developing countries to replace the slogan-based "Basic Four" to "Nutrition Guide for Balanced Diet". This emphasis is based on the fact that developing countries have to face the double burden of nutrition problems (malnutrition and over nutrition). Principle slogan "Nutrition Guide for Balanced Diet": consumption daily diet should contain nutrients in the type and amount (portion) that fits the needs of each individual or age group. Consumption of food with this pattern should pay attention to four basic principles, namely: Diversity of food; Regular physical activity and measurable; personal and environmental hygiene are maintained; and monitor or maintain weight is always ideal.
\end{abstract}

Keywords: The guidelines of balanced nutrition, nutritional status, clinical symtomps

\begin{abstract}
ABSTRAK
Gizi yang baik akan sejalan dengan kesehatan yang baik. Pada gejala klinis dari kekurangan nutrisi adalah pertumbuhan dan perkembangan tubuh tidak normal. Staus gizi merupakan hasil akhir dari berbagai faktor yang dapat saling terkait satu sama lain. Oleh karena itu memahami bagaimana terjadinya masalah gizi seharusnya menjadi dasar dalam menetapkan strategi pencegahan dan penanggulangannya. Status gizi secara langsung dipengaruhi oleh dua hal, yaitu kecukupan asupan gizi dalam memenuhi kebutuhan tubuh dan status infeksi seseorang, yang saling berpengaruh, sehingga memperbaiki salahsatunya tidak akan memperbaiki keadaan yang lainnya. Oleh karena itu Pedoman Gizi Seimbang (PGS) menjadi jalan keluar terbaik di Indonesia divisualisasikan dalam Tumpeng Gizi Seimbang.Data status gizi dan kesehatan serta penyakit tidak menular terkait gizi diperoleh dari data Riset Kesehatan Dasar (Riskesdas) oleh Kemenkes, 2010 dan data status gizi mikro, khususnya status anemia defisiensi zat besi. Hasil kesepakatan Konferensi Pangan Sedunia di Roma tahun 1992 menetapkan rekomendasi kepada semua negara terutama negara-negara sedang berkembang untuk mengganti slogan yang berbasis "Basic Four" menjadi "Nutrition Guide for Balanced Diet". Penekanan ini didasarkan atas kenyataan bahwa negara-negara berkembang telah menghadapi beban ganda masalah gizi (gizi kurang maupun gizi lebih). Prinsip slogan"Nutrition Guide for Balanced Diet" yaitu konsumsi makanan sehari-hari harus mengandung zat gizi dalam jenis dan jumlah (porsi) yang sesuai dengan kebutuhan setiap orang atau kelompok umur. Konsumsi makanan dengan pola ini harus memperhatikan empat prinsip dasar yaitu : Keanekaragaman pangan; aktivitas fisik yang teratur dan terukur; kebersihan diri dan lingkungan yang terjaga; serta pantau atau pertahankan berat badan selalu ideal.
\end{abstract}

Kata kunci: PGS, status gizi, gejala klinis

\section{Masalah gizi}

Gizi yang baik akan sejalan dengan kesehatan yang baik. Pada gejala klinis dari kekurangan nutrisi adalah pertumbuhan dan perkembangan tubuh tidak normal. Staus gizi merupakan hasil akhir dari berbagai faktor yang dapat saling terkait satu sama lain. Oleh karena itu memahami bagaimana terjadinya masalah gizi seharusnya menjadi dasar dalam menetapkan strategi pencegahan dan penanggulangannya. Status gizi secara langsung dipengaruhi oleh dua hal, yaitu kecukupan asupan gizi dalam memenuhi kebutuhan tubuh dan status infeksi seseorang, yang saling berpengaruh, sehingga memperbaiki

\footnotetext{
${ }^{1}$ Program Studi Teknologi Pangan Fakultas Teknologi Pertanian Universitas Widya Mataram Yogyakarta Email: dtl.titin@yahoo.com
} 
salahsatunya tidak akan memperbaiki keadaan yang lainnya.

Kurangnya asupan zat gizi akan menyebabkan seseorang mengalami defisit dalam memenuhi kebutuhan tubuhnya, dan salah satu konsekuensinya adalah menjadi rentan terhadap serangan penyakit infeksi, yang apabila terjadi akan memperburuk status gizinya. Sebaliknya seseorang yang menderita penyakit infeksi akan mengalami peningkatan metabolisme dan suhu tubuh, yang menyebabkan kebutuhan energi dan zat-zat gizinya meningkat. Sementara itu, seseorang yang menderita penyakit infeksi biasanya mengalami penurunan nafsu makan, sehingga asupan gizinya juga berkurang, yang jika berlangsung lama akan menurunkan status gizinya (UNICEF, 1998).

Pola asuh orang tua yang baik, asupan gizi dan kejadian penyakit infeksi sangat dipengaruhi oleh akar masalah, yang meliputi faktor sosial akan ekonomi, sosial dan budaya. Pola asuh orang tua merupakan faktor yang sangat penting dan memberikan peluang untuk ditingkatkan, antara lain melalui penyampaian informasi gizi dan Tabel 1. Berbagai kelompok umur dan PTM (Penyakit Tidak Menular)

\begin{tabular}{|c|c|c|}
\hline No . & Kelompok & PTM \\
\hline 1. & Remaja dan Prahamil & $\begin{array}{l}\text { *Stunting } \\
\text { *Kurang Energi Kronis (KEK) } \\
\text { *Anemia } \\
\text { *Overweight dan Obese }\end{array}$ \\
\hline 2. & Ibu hamil, nifas dan menyusui & $\begin{array}{l}\text { *Stunting } \\
\text { *Kurang Energi Kronis (KEK) } \\
\text { *Anemia } \\
\text { *Overweight dan Obese } \\
\text { *Kurang Vitamin A } \\
\text { *GAKI (Gangguan Akibat Kurang Iodium) }\end{array}$ \\
\hline 3. & Bayi dan Anak Balita & $\begin{array}{l}\text { *BBLR (Bayi Berat Lahir Rendah) } \\
\text { *Stunting } \\
\text { *Anemia } \\
\text { *Kurang Vitamin A } \\
\text { *GAKI (Gangguan Akibat Kurang Iodium) } \\
\text { *Underweight } \\
\text { *Overweight dan Obese }\end{array}$ \\
\hline 5. & Dewasa dan Lanjut Usia & $\begin{array}{l}\text { *Wasting } \\
\text { *Stunting } \\
\text { *Anemia } \\
\text { *Kurang Vitamin A } \\
\text { *GAKI (Gangguan Akibat Kurang Iodium) } \\
\text { *Underweight } \\
\text { *Overweight dan Obese } \\
\text { *Anemia } \\
\text { *Overweight dan Obese } \\
\text { *PTM terkait Gizi }\end{array}$ \\
\hline
\end{tabular}

Sumber : Anonim, 2013

Secara luas pengkajian penyakit bertujuan untuk memberi informasi tentang status gizi dan untuk

mengetahui bahaya dari kekurangan nutrisi. Berbagai penelitian terkini semakin kuat kesehatan secara benar sehingga akan mengubah pengetahuan, persepsi dan pola asuh gizi dan kesehatannya, yang pada akhirnya akan memberikan pengaruh baik terhadap status gizi anaknya.

Data status gizi dan kesehatan serta penyakit tidak menular terkait gizi diperoleh dari data Riset Kesehatan Dasar (Riskesdas) oleh Kemenkes, 2010 dan data status gizi mikro, khususnya status anemia defisiensi zat besi (Riskesdas, 2007).

Dengan menggunakan tiga indikator antropometri, yakni indikator menurut umur $(\mathrm{BB} / \mathrm{U})$, $\mathrm{TB}$ menurut Umur $(\mathrm{TB} / \mathrm{U})$ dan $\mathrm{BB}$ menurut $\mathrm{TB}$ (BB/TB) atau IMT (Indeks Massa Tubuh). Akan diketahui karakteristik masalah gizi yang dihadapi, tergolong gizi akutkah, kronis atau akutkronis. Selain itu juga dapat diketahui arah masalah gizi salah (malnutrition) termasuk underweight dan overweight atau keduanya.

Masalah gizi yang sering terjadi pada berbagai kelompok umur dan penyakit tidak menular adalah sebagai berikut pada Tabel 1.: 
mendukung pengaruh kekurangan gizi pada masa sangat dini dalam kehidupan, yaitu sejak janin sampai dua tahun pertama kehidupan yang disebut sebagai 1000 hari pertama kehidupan (masa emas).

Pengaruh gangguan gizi pada masa ini sangat luar biasa karena pengaruhnya tidak hanya terhadap perkembangan fisik, tetapi juga yang lebih penting terhadap perkembangan kognitif yang nantinya berpengaruh terhadap kecerdasan dan ketangkasan berpikir dan terhadap produktivitas kerja. Kekurangan gizi pada masa ini juga dikaitkan dengan risiko terjadinya penyakit kronis pada usia dewasa, yaitu obesitas, hipertensi, penyakit jantung, stroke dan diabetes atau penyakit tidak menular (PTM) lainnya.

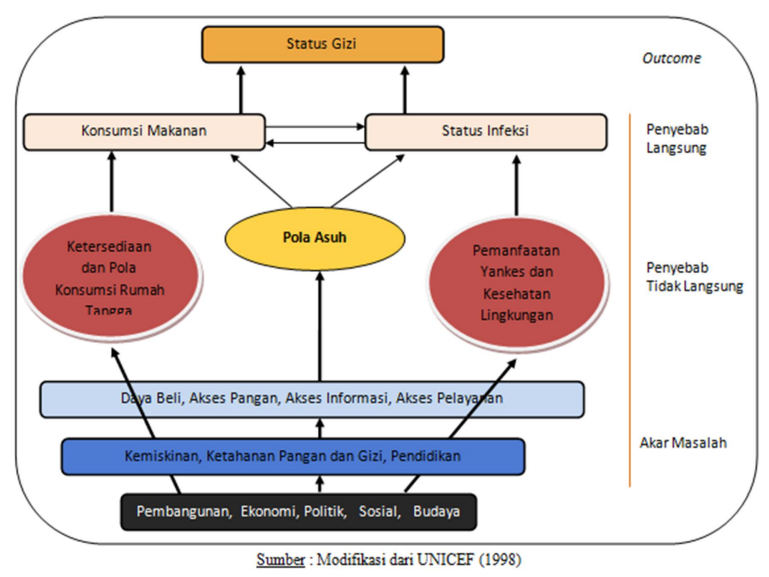

Gambar 1. Kerangka konsep terjadinya masalah gizi

\section{Pedoman gizi seimbang}

Kemajuan teknologi pangan yang diiringi dengan kemajuan yang pesat dalam bidang teknologi informasi dan komunikasi (gadget), telah menggiring masyarakat untuk mengonsumsi berbagai makanan instan secara tidak proporsional bahkan berlebih dikarenakan praktis dalam penyajiannya. Masalah dengan konsumsi makanan jadi atau setengah jadi yang diawetkan antara lain jumlah energi total, zat-zat gizi tertentu yang berlebihan/tidak proporsional, kandungan zat aditif yang tidak hanya satu jenis bisa lebih dalam satu jenis makanan tertentu, sehingga dalam waktu lama akan berpengaruh negatif terhadap kesehatan baik secara langsung maupun tidak langsung.

Akhir-akhir ini diketahui bahwa perkembangan ilmu dalam bidang pangan dan gizi sangatlah pesat, baik yang berdampak positif maupun negatif terhadap status gizi dan kesehatan masyarakat. Kemajuan ilmu telah membantu para pakar dan ahli gizi untuk lebih mengerti mengenai peran zat-zat gizi terhadap kesehatan manusia, serta mekanisme terjadinya suatu fenomena atau perubahan dalam tubuh seseorang. Berbagai temuan telah semakin mengokohkan peran gizi sebagai pencegah berbagai penyakit antara lain peran asam lemak omega -3 dan -6 , serta antioksidan dan berbagai senyawa fitokimia/bahan organik sekunder dari tanaman pangan.

\begin{tabular}{|c|c|c|c|c|}
\hline $\begin{array}{c}\text { Fetal \& } \\
\text { Infant } \\
\text { nutrition }\end{array}$ & $\begin{array}{c}\underline{\text { Short term }} \\
\text { Brain Development }\end{array}$ & $\rightarrow$ & \begin{tabular}{l}
\multicolumn{1}{c}{ Long term } \\
Cognitive Capacity \& \\
Education \\
Culture
\end{tabular} & $\begin{array}{l}\text { School Failure } \\
\text { Poor Education } \\
\text { Lower Income }\end{array}$ \\
\hline GENES & $\begin{array}{l}\text { Growth muscle/bone } \\
\text { Weight \& HEIGHT } \\
\text { Body Composition }\end{array}$ & $\rightleftarrows$ & $\begin{array}{l}\text { Immunity } \\
\text { Locomotion } \\
\text { WorkCapacity }\end{array}$ & $\begin{array}{l}\text { Infections } \\
\text { Stunting } \\
\text { Lower Income }\end{array}$ \\
\hline $\begin{array}{l}\downarrow \\
\text { Infection } \\
\text { and other } \\
\text { Epigenetic } \\
\text { Factors }\end{array}$ & $\begin{array}{l}\text { Growth muscle/bone } \\
\text { Weight \& HEIGHT } \\
\text { Body Composition }\end{array}$ & $\rightarrow$ & $\begin{array}{l}\text { Fuel to support brain } \\
\text { activity } \\
\text { Energy stores for } \\
\text { survival feast/famine } \\
\text { Insulin resistance }\end{array}$ & $\begin{array}{l}\text { Obesity } \\
\text { Diabetes } \\
\text { Coronary HD } \\
\text { High BP/Stroke } \\
\text { Cancer } \\
\text { Age Related } \\
\text { functional loss }\end{array}$ \\
\hline
\end{tabular}

Gambar 2. Dampak jangka pendek dan panjang akibat gangguan gizi.

Untuk menghadapi masalah gizi tersebut, diperlukan adanya upaya untuk mengubah pola konsumsi makanan di Indonesia agar konsumsi zat gizi sesuai dengan kebutuhan. Pada era tahun limapuluhan tepatnya 1952 slogan 4sehat 5sempurna diperkenalkan oleh Bapak Gizi Indonesia Prof. Poerwo Sudarmo, yakni makan dengan menu makanan yang terdiri dari makanan pokok, lauk pauk, sayur mayur dan buah serta minum susu untuk menyempunakan menu tersebut. Dalam perkembangannya hasil kesepakatan Konferensi Pangan Sedunia di Roma tahun 1992 menetapkan rekomendasi kepada semua negara terutama negara-negara sedang berkembang untuk mengganti slogan yang berbasis "Basic Four" menjadi "Nutrition Guide for Balanced Diet". Penekanan ini didasarkan atas kenyatan bahwa negara-negara berkembang telah menghadapi beban ganda masalah gizi (gizi kurang maupun gizi lebih). Di satu pihak masalah kekurangan gizi belum mampu teratasi dengan baik, di lain pihak terjadi peningkatan prevalensi kelebihan gizi yang diikuti meningkatnya prevalensi PTM (Anonim, 2013). 
Prinsip slogan"Nutrition Guide for Balanced Diet" yaitu konsumsi makanan seharihari harus mengandung zat gizi dalam jenis dan jumlah (porsi) yang sesuai dengan kebutuhan setiap orang atau kelompok umur. Konsumsi makanan dengan pola ini harus memperhatikan empat prinsip dasar yaitu : eanekaragaman pangan; aktivitas fisik yang teratur dan terukur; kebersihan diri dan lingkungan yang terjaga; serta pantau atau pertahankan berat badan selalu ideal.

Departemen Kesehatan RI mengeluarkan Pedoman Umum Gizi Seimbang dengan Tabel 2. PGS di beberapa negara.

\begin{tabular}{|c|c|c|c|c|c|}
\hline No. & Negara & Judul PGS & Tahun & $\begin{array}{c}\text { Jumlah } \\
\text { Pesan }\end{array}$ & Grafis Pedoman Makanan \\
\hline 1. & China & $\begin{array}{l}\text { Dietary Guidlines for Chinese } \\
\text { Residents }\end{array}$ & 2007 & 8 & Pagoda (Ge, 2011) \\
\hline 2. & Jepang & Dietary Guidlines for Japanese & 2000 & 10 & $\begin{array}{l}\text { Spinning Top (Yoshiike et al, } \\
\text { 2007) }\end{array}$ \\
\hline 3. & Malaysia & Malaysian Dietary Guidlines & 2010 & 14 & Pyramid (Tee, 2011) \\
\hline 4. & Thailand & $\begin{array}{l}\text { The Thai Dietary Guidlines for } \\
\text { Better Health }\end{array}$ & 1995 & 9 & Flag (Sirichakwa et al, 2011) \\
\hline 5 & Indonesia & 13 Pesan Dasar Gizi Seimbang & 2003 & 13 & Tumpeng (Anonim, 2003) \\
\hline 6. & Australia & Australian Dietary Guidlines & 2013 & 5 & $\begin{array}{l}\text { Bundar } \\
\text { (Australian Government, } \\
\text { 2013) }\end{array}$ \\
\hline 7. & $\begin{array}{l}\text { Amerika } \\
\text { Serikat }\end{array}$ & $\begin{array}{l}\text { MyPlate (US Government) } \\
\text { Healthy Eating Plate (Harvard) }\end{array}$ & 2011 & 10 & $\begin{array}{l}\text { MyPlate (US Departement of } \\
\text { Agriculture, 2010) }\end{array}$ \\
\hline
\end{tabular}

Di Amerika menganjurkan makan sayuran dan buah sebagai setengah bagian dari makanan total, dengan penjelasan 10 tip yakni :

1. Balance calorie (berdasarkan $\mathrm{BB}, \mathrm{TB}$, umur dan tingkat aktivitas fisik)

2. Nikmati makanan yang dimakan

3. Hindari makan porsi berlebihan (pilih piring atau mangkuk yang kecil)

4. Makan lebih banyak sayuran, buah, whole grains, makanan berlemak rendah.

5. Isi separuh piring dengan sayuran dan buah

6. Ganti ke makanan bebas lemak atau rendah lemak, hindari lemak hewani

7. Setengah dari padi-padian yang whole grains (oatmeal, beras merah dll)

8. Makanan yang harus dikurangi (makanan tinggi lemak, gula dan garam) serta visualisasi dalam bentuk tumpeng gizi seimbang. Pengembangan PGS (Pedoman Gizi Seimbang) di berbagai negara telah melakukan penyesuaian yang spesifik untuk masing-masing negara. Secara umum semua memiliki kecenderungan yang sama tetapi negara tertentu disesuaikan dengan aspek agam dan pola makanan yang sudah ada seperti contoh India mempunyai visualisasi 2 piramida gizi seimbang yaitu bagi vegetarian dan nonvegetarian. Tabel 2 menunjukkan PGS di beberapa negara. makanan olahan seperti (cake dan cookies, sosis dll).

9. Bandingkan natrium di label makanan. Pilih yang low sodium, reduced salt atau no sald added).

10. Pilih minum air bukan minuman manis, bersoda, berenergi dll.

Pedoman Gizi Seimbang (Dietary Guidlines) yang digunakan di negara maju sebagai pedoman makan dan beraktivitas sehat untuk masyarakat. Di Indonesia Tumpeng Gizi Seimang direkomendasikan untuk pengembangan pesan gizi seimbang.

\section{Daftar pustaka}

Anonim, 2003.Pedoman Umum Gizi Seimbang : Panduan untuk Petugas. Dit Gizi 
Masyarakat Ditjend Binkesmas.

Departemen Kesehatan RI. Jakarta.

Anonim, 2010. Riset Kesehatan Dasar (Riskesdas)

Badan Penelitian dan Pengembangan

Kesehatan Balitbangkes Kementerian

Kesehatan RI. Jakarta.

Anonim, 2013. Naskah Akademik Pedoman Gizi

Seimbang (PGS) Direktorat Jenderal Bina

Gizi dan KIA Kemenkes. RI. Jakarta.

Australian Government, 2013. Australian

Government-National Health \& Medical research Council and Departement of Health and Ageing. Eat for HealthAustralian Dietary Guidelines: Providing the Scientific Evidence for Healthier Australian Diets. Commonwealth of Australia.

Ge K., 2011. The transition of Chinese dietary guidelines and the food guide pagoda. Asia Pac J Clin Nutr; 20 (3): 439-46

Sirichakwal PP, Sranacharoenpong K, dan Tontisirin K., 2011, Food based dietary guidelines (FBDGs) development and promotion in Thailand. Asia Pac. J Clin Nutr : 20 (3) : 477-83.

Tee ES., 2011. Development and Promotion of Malaysian Dietary Guidelines.

Uauy R., Kain J, dan Corvalan C., 2011. How can the Developmental Origins of Health and Disease (DOHaD) hypothesis contribute to improving health in Developing contries ? Am j Clin Nutr; 94 (suppl) : 1759S-64S.

UNICEF, 1998. The State of The Word's Children. Oxford and New York. Oxford University Press.

US Departement of Agriculture, 2010. US Departement of Health and Human Services, Dietary Guidelines for Americans 7edition. Washington DC: US Govermment Printing Office

Yoshiike N, Hayashi F, Takemi Y, Mizoguchi K, dan Seino FA., 2007. New food guide in Japan: The Japanese food guide Spinning Top. Nutr Rev; 65(4): 149-54 